\title{
CD248 and integrin alpha-8 are candidate markers for differentiating lung fibroblast subtypes
}

Sayomi Matsushima ${ }^{1,2}$, Yoichiro Aoshima ${ }^{1,2}$, Taisuke Akamatsu ${ }^{3}$, Yasunori Enomoto ${ }^{1,2}$, Shiori Meguro ${ }^{1}$, Isao Kosugi ${ }^{1}$, Hideya Kawasaki ${ }^{1}$, Tomoyuki Fujisawa ${ }^{2}$, Noriyuki Enomoto ${ }^{2}$, Yutaro Nakamura ${ }^{2}$, Naoki Inui ${ }^{4}$, Kazuhito Funai ${ }^{5}$, Takafumi Suda ${ }^{2}$ and Toshihide Iwashita ${ }^{1 *}$ (D)

\begin{abstract}
Background: Lung fibrosis is a serious life-threatening condition whose manifestation varies according to the localization and characteristics of fibroblasts, which are considered heterogeneous. Therefore, to better understand the pathology and improve diagnosis and treatment of this disease, it is necessary to elucidate the nature of this heterogeneity and identify markers for the accurate classification of human lung fibroblast subtypes.

Methods: We characterized distinct mouse lung fibroblast subpopulations isolated by fluorescence-activated cell sorting (FACS) and performed microarray analysis to identify molecular markers that could be useful for human lung fibroblast classification. Based on the expression of these markers, we evaluated the fibroblast-like cell subtype localization in normal human lung samples and lung samples from patients with idiopathic pulmonary fibrosis (IPF).

Results: Mouse lung fibroblasts were classified into Sca- $1^{\text {high }}$ fibroblasts and Sca-1 ${ }^{\text {low }}$ fibroblasts by in vitro biological analyses. Through microarray analysis, we demonstrated CD248 and integrin alpha-8 (ITGA8) as cell surface markers for Sca- ${ }^{\text {high }}$ fibroblasts and Sca- $1^{\text {low }}$ fibroblasts, respectively. In mouse lungs, Sca- $1^{\text {high }}$ fibroblasts and Sca-1 ${ }^{\text {low }}$ fibroblasts were localized in the collagen fiber-rich connective tissue and elastic fiber-rich connective tissue, respectively. In normal human lungs and IPF lungs, two corresponding major fibroblast-like cell subtypes were identified: CD248 $8^{\text {high }}$ ITGA ${ }^{\text {low }}$ fibroblast-like cells and CD248 ${ }^{\text {low }}$ ITGA ${ }^{\text {high }}$ fibroblast-like cells, localized in the collagen fiber-rich connective tissue and in the elastic fiber-rich connective tissue, respectively.

Conclusion: CD248 ${ }^{\text {high }}$ ITGA ${ }^{\text {low }}$ fibroblast-like cells and CD248 ${ }^{\text {low }}$ ITGA $8^{\text {high }}$ fibroblast-like cells were localized in an almost exclusive manner in human lung specimens. This human lung fibroblast classification using two cell surface markers may be helpful for further detailed investigations of the functions of lung fibroblast subtypes, which can provide new insights into lung development and the pathological processes underlying fibrotic lung diseases.
\end{abstract}

Keywords: Fibroblast, Lung, Fibrosis, Collagen fibers, Elastic fibers, Idiopathic pulmonary fibrosis

\section{Background}

Fibroblasts play crucial roles in the wound-healing process by producing an extracellular matrix, which comprises collagen and elastic fibers, for appropriate tissue remodeling [1]. Fibroblasts show various localization patterns, even within a single organ, and each of these populations may

\footnotetext{
* Correspondence: toshiiwa@hama-med.ac.jp

'Department of Regenerative and Infectious Pathology, Hamamatsu

University School of Medicine, 1-20-1 Handayama, Higashi-ku, Hamamatsu

City, Shizuoka 431-3192, Japan

Full list of author information is available at the end of the article
}

show different characteristics [2]. Recently, this fibroblast heterogeneity has become a research topic of interest with respect to the role of fibroblasts in cancer development $[3,4]$.

In the presence of persistent stimuli, the repair of injured tissue may be accomplished by replacing normal parenchymal tissue with fibrotic tissue. Lung fibrosis often leads to respiratory failure, representing a lifethreatening condition. In idiopathic pulmonary fibrosis (IPF), a representative lethal lung fibrotic disease, fibrosis is predominant in the perilobular (subpleural and/or

(c) The Author(s). 2020 Open Access This article is distributed under the terms of the Creative Commons Attribution 4.0 International License (http://creativecommons.org/licenses/by/4.0/), which permits unrestricted use, distribution, and reproduction in any medium, provided you give appropriate credit to the original author(s) and the source, provide a link to the Creative Commons license, and indicate if changes were made. The Creative Commons Public Domain Dedication waiver (http://creativecommons.org/publicdomain/zero/1.0/) applies to the data made available in this article, unless otherwise stated. 
paraseptal) region [5]. To better understand the heterogeneity of fibrosis in IPF, it is first necessary to identify fibroblast subtypes, as well as their localization patterns, and to elucidate their distinct roles. However, molecular markers for human lung fibroblast subtypes have not yet been well established. Therefore, the discovery of a set of markers that may be used to define different human fibroblast subtypes is necessary.

Toward this end, we sought to identify candidate fibroblast markers using microarray analysis of the distinct fibroblasts of the adult mouse lung. Two cell surface markers, CD248 and integrin alpha-8 (ITGA8), were ultimately selected as potentially useful for the identification of human lung fibroblast-like cell subtypes. Based on the expression of these markers, we further evaluated the fibroblast-like cell subtype localization in human samples of normal lungs and the lungs of patients with IPF.

\section{Methods}

\section{Animal experiments}

C57BL/6 female mice (12-16-week-old; $25 \mathrm{~g}$ ) were purchased from SLC (Shizuoka, Japan). The mice were bred and housed in a pathogen-free mouse facility at a constant temperature and humidity under a 12-h light/12-h dark cycle. All mice were maintained on the sterilized plastic cages containing wood chip bedding and ad libitium access to water and food.

\section{Fluorescence-activated cell sorting (FACS) analysis}

The mice were anesthetized by intraperitoneal administration of pentobarbital sodium $(77.8 \mu \mathrm{g} / \mathrm{g}$ body mass) (Kyoritsu Seiyaku, Tokyo, Japan) and then sacrificed by $\mathrm{CO}_{2}$ asphyxiation. To prepare a single-cell suspension from the mouse lungs for FACS analysis, the lungs were incubated with $200 \mathrm{U} / \mathrm{mL}$ of collagenase type 2 (Worthington, Lakewood, NJ, USA) and $100 \mathrm{U} / \mathrm{mL}$ DNase I (Worthington) for $30 \mathrm{~min}$ at $37^{\circ} \mathrm{C}$ in Dulbecco's phosphate-buffered saline (PBS; Gibco, Carlsbad, CA, USA) [6]. The tissue was cut using gentleMACS Dissociator (Miltenyi Biotechnology, Bergisch Gladbach, Germany). After removing cell aggregates, the obtained suspension was centrifuged at $200 \times g$ and rinsed twice using FACS buffer (1\% HEPES, $2 \%$ heat-inactivated fetal calf serum, $120 \mu \mathrm{g} / \mathrm{mL}$ penicillin, and $100 \mu \mathrm{g} / \mathrm{mL}$ streptomycin in Hanks' buffered salt solution).

In addition to platelet-derived growth factor receptor A (PDGFRA), stem cell antigen-1 (Sca-1) and thymus cell antigen-1 (Thy-1) are used as molecular markers for identifying mouse fibroblasts [6-12]. Single cells were incubated with phycoerythrin (PE)-conjugated anti-PDGFRA antibody, PE-Cy7-conjugated anti-Sca-1 antibody, and PerCpCy5.5-conjugated anti-Thy-1.2 antibody; antibodies against lineage-specific cell surface markers allophycocyanin
(APC)-conjugated anti-CD31 (vascular endothelial cells), anti-CD45 (hematopoietic cells), anti-CD146 (pericytes and smooth muscle cells), anti-E-cadherin (epithelial cells), antiLYVE1 (lymphatic endothelial cells), and anti-TER-119 (erythrocytes) (Additional file 1: Table S1); and Sytox Red Dead Cell Stain (1:1000) (Thermo Fisher Scientific, Waltham, MA, USA) for $30 \mathrm{~min}$ on ice. After centrifugation $(200 \times g)$ and rinsing of the sample twice in FACS buffer, sorting and analysis were performed using FACSAria (BD Biosciences, San Diego, CA, USA).

To discriminate between ITGA8-positive and ITGA8negative fibroblasts, single cells were incubated as well with biotin-conjugated anti-ITGA8 antibody (Additional file 1: Table S1) in addition to the antibodies described above. As an isotype control, biotin-conjugated goat IgG antibody (Abcam, Cambridge, UK) was used. After centrifuging $(200 \times g)$ and rinsing twice in FACS buffer, cells were incubated with Alexa 488-conjugated streptavidin (Thermo Fisher Scientific) for $30 \mathrm{~min}$ on ice, after which they were centrifuged $(200 \times g)$ and rinsed twice in FACS buffer again, and sorting and analysis were performed using FACSAria.

\section{Cell culture, colony-forming unit (CFU) assay, cell counting, and immunocytochemistry}

Isolated batches of 200 cells in 6-well plates (Grainer bio-one, Kremsmünster, Austria) were grown in Dulbecco's modified Eagle medium (DMEM; Gibco) supplemented with Glutamax (Gibco), $120 \mu \mathrm{g} / \mathrm{mL}$ penicillin, $100 \mu \mathrm{g} / \mathrm{mL}$ streptomycin, and 20\% heat-inactivated fetal calf serum (Gibco) at $37{ }^{\circ} \mathrm{C}$ in an atmosphere with $2 \%$ $\mathrm{O}_{2}$ and $5 \% \mathrm{CO}_{2}$. The cultured cells were incubated with $1 \mu \mathrm{g} / \mathrm{mL}$ propidium iodide (PI; Sigma-Aldrich, St Louis, MO, USA) for $10 \mathrm{~min}$ at $25^{\circ} \mathrm{C}$, fixed in $4 \%$ paraformaldehyde for $10 \mathrm{~min}$ at $25^{\circ} \mathrm{C}$, and stained with $1 \mu \mathrm{g} / \mathrm{mL}$ Hoechst 33342 (Sigma-Aldrich). For the CFU assay, the colonies consisting of more than 50 viable cells (Hoechst 33342-positive/PI-negative cells) were counted at day 7 of culture. To investigate the proliferative potential, all Hoechst 33342-positive/PI-negative cells in one well of the plates were counted as viable cells in three independent samples in triplicate at days of 1 and 7 of culture. A total of six mice were used for these experiments.

Immunocytochemical staining was performed at day 7 of culture. The adherent cells were fixed in $4 \%$ paraformaldehyde for $10 \mathrm{~min}$ at $25^{\circ} \mathrm{C}$ and permeabilized with $0.5 \%$ Triton X-100 in PBS for 5 min at $25^{\circ} \mathrm{C}$. The cells were then incubated in blocking solution (10\% goat serum and $0.1 \%$ Triton $\mathrm{X}-100$ in PBS) for $30 \mathrm{~min}$ at $25^{\circ} \mathrm{C}$, followed by unconjugated anti- $\alpha$ SMA antibody (Additional file 1: Table S1) and $1 \mu \mathrm{g} / \mathrm{mL}$ Hoechst 33342 in blocking solution, and were finally incubated with Alexa-Fluor 488-conjugated anti-mouse $\mathrm{IgG}_{2 \mathrm{a}}$ antibody. 
Cells were imaged using an Olympus IX71 fluorescence microscope (Olympus). Images were captured using a DP70 camera (Olympus), and subsequently postprocessed using Adobe Photoshop CS3.

\section{Protein quantification of aSMA using FACS}

Each fibroblast subpopulation cultured for 7 days was centrifuged; the cells were fixed in $10 \%$ buffered formalin for $15 \mathrm{~min}$ at $25^{\circ} \mathrm{C}$, and then permeabilized for $5 \mathrm{~min}$ using IntraPrep (Beckman Coulter, Brea, CA, USA) according to the manufacturer's instructions. After centrifuging and rinsing in FACS buffer, the cells were incubated with fluorescein isothiocyanate (FITC)-conjugated anti- $\alpha$ SMA antibody for $30 \mathrm{~min}$ at $25^{\circ} \mathrm{C}$. As an isotype control, FITC-conjugated anti-mouse IgG2a (Thermo Fisher Scientific) was used. After centrifuging and rinsing in FACS buffer, the FITC fluorescence intensity of the cells was measured using the FACSAria system. Flow cytometry analysis was performed in triplicate using three independent samples.

Adipogenic differentiation and osteogenic differentiation Isolated batches of 800 cells of A- and B-type fibroblasts, and 3000 cells of C-type fibroblasts were grown in 24well plates (Grainer bio-one) in DMEM supplemented with Glutamax (1:100), $120 \mu \mathrm{g} / \mathrm{mL}$ penicillin, $100 \mu \mathrm{g} / \mathrm{mL}$ streptomycin, and $20 \%$ heat-inactivated fetal calf serum at $37^{\circ} \mathrm{C}$ in an atmosphere with $2 \% \mathrm{O}_{2}$ and $5 \% \mathrm{CO}_{2}$ until they visibly reached confluence. Furthermore, confluent cells were cultured in adipogenic differentiation medium containing $0.5 \mathrm{mM}$ isobutyl-methylxanthine (Sigma-Aldrich), $1 \mu \mathrm{M}$ dexamethasone (Sigma-Aldrich), and $2.0 \mu \mathrm{M}$ insulin (Sigma-Aldrich) for 2 days and maintained in medium with $2.0 \mu \mathrm{M}$ insulin for an additional 2 days. The cells were then maintained in DMEM with $20 \%$ fetal calf serum until day 8 . The cells were fixed in $4 \%$ paraformaldehyde, stained using Oil Red-O (SigmaAldrich) to detect cytoplasmic triglycerides, and incubated with unconjugated anti-fatty acid binding protein 4 (FABP4) (Additional file 1: Table S1) and Alexa-Fluor 488-conjugated anti-rabbit IgG antibodies. A total of nine mice were used for these experiments.

Confluent cells were cultured in osteogenic differentiation medium containing $100 \mathrm{nM}$ dexamethasone (Sigma-Aldrich), $0.2 \mathrm{mM}$ ascorbic acid (Sigma-Aldrich), and $10 \mathrm{mM} \beta$-glycerophosphate (Sigma-Aldrich) for 21 days. The medium was changed every 3 days, and cells were stained by the von Kossa stain (Sigma-Aldrich) to detect calcium deposition. A total of nine mice were used for this experiment.

\section{Gene expression profiling}

Approximately 7500, 3000, and 7500 A-, B-, and C-type fibroblasts were obtained, respectively, from one mouse.
Total RNA was extracted from two independently prepared samples of 50,000 fibroblasts from each of the distinct populations identified by FACS analysis, and from single pulmonary cells $(\mathrm{Pu})$ freshly isolated from the adult mouse lungs using RNeasy Mini Kit (Qiagen, Hilden, Germany). The total RNA was amplified using Ovation PicoSL WTA System V2 (NuGen, San Carlos, CA, USA). Cyanine-3-labeled cDNA was prepared from $2.0 \mu \mathrm{g}$ DNA using the SureTag Complete DNA Labeling Kit (Agilent, Santa Clara, CA, USA). Cyanine-3-labeled cDNA was hybridized to the Mouse $8 \times 60 \mathrm{~K}(39,430$ genes) (Agilent) array. After scanning, the obtained raw data were normalized. The average ( $\log _{2}$-transformed) gene expression values were calculated, and the obtained values were labeled according to the distinct cell types: $\mathrm{Pu}$, and $\mathrm{A}-, \mathrm{B}-$, and $\mathrm{C}$-type fibroblasts (Additional file 1: Table S2-4). The identification strategy used for Sca$1^{\text {low }}$ (C-type fibroblasts) and Sca- $1^{\text {high }}$ (A- and B-type fibroblasts) mouse fibroblast-specific genes is described in the footnote to Additional file 1: Table S3 and S4, respectively. A total of 40 mice were used for these experiments.

\section{Quantitative polymerase chain reaction (qPCR)}

The details of the qPCR procedure were described elsewhere [6]. Primer sequences are listed in Additional file 1: Table S5.

\section{Immunofluorescence staining for adult mouse lungs}

After the lung samples obtained from C57BL/6 mice in optimal cutting temperature formulation (Sakura Finetek, Tokyo, Japan) had been frozen at $-80^{\circ} \mathrm{C}$ in organic solvent, $6-\mu \mathrm{m}$ thick slices, sectioned at $-20^{\circ} \mathrm{C}$ using a cryostat, were fixed in cold acetone for $10 \mathrm{~min}$ and dried for $20 \mathrm{~min}$ at $25^{\circ} \mathrm{C}$. The sections were incubated in the blocking solution without detergent (10\% goat serum in PBS) for $30 \mathrm{~min}$ at $25^{\circ} \mathrm{C}$, after which they were incubated with the appropriate primary antibody (Additional file 1: Table S1) and $1 \mu \mathrm{g} / \mathrm{mL}$ Hoechst 33342 in the blocking solution for $30 \mathrm{~min}$ at $25^{\circ} \mathrm{C}$, and were washed in PBS. When anti-ITGA8 antibody (biotin-conjugated) was used, samples were incubated with Alexa-Fluor conjugated streptavidin (Thermo Fisher Scientific). The sections were mounted in Prolong Gold (Thermo Fisher Scientific) and imaged with TSC SP8 confocal microscope (Leica, Wetzlar, Germany). Images were processed with LAS X software (Leica), and then Adobe Photoshop CS3 (Adobe Systems, Inc., San Jose, CA, USA) was used to superimpose three different color images.

\section{Human tissue samples}

From the archives of Hamamatsu University School of Medicine Hospital, we retrieved four human lung samples from autopsy cases without lung disease (normal 
lungs) and ten human lung biopsy samples by videoassisted thoracic surgery (VATS) from patients with IPF (Additional file 1: Table S6). In addition, we retrieved human skin, large intestine, heart, kidney, and liver samples from autopsy cases. Sequential $4-\mu$ m-thick sections from formalin-fixed and paraffin-embedded (FFPE) human lung samples were prepared for hematoxylin and eosin staining, Elastica van Gieson (EVG) staining, conventional immunohistochemistry (IHC), and multiplex immunofluorescence.

\section{IHC for human samples}

Conventional IHC analyses using anti-CD248 and antiITGA8 antibodies (Additional file 1: Table S1) were performed after antigen retrieval. The slides were imaged with a BX51 fluorescence microscope (Olympus, Tokyo, Japan). Images were processed with CellSens software (Olympus).

\section{Multiple immunofluorescence staining for FFPE human lung samples}

We used Opal ${ }^{\text {mo }}$ 4-color Manual IHC Kit (Perkin Elmer, Waltham, MA, USA), a method for multiplex immunofluorescence staining of FFPE tissues, which uses individual tyramide signal amplification (TSA)-conjugated fluorophores to detect various antigens on one slide. This method enables the use of multiple primary antibodies raised in the same species.

Lung tissue sections were deparaffinized and rehydrated, and the antigen retrieval was performed in a microwave to boil for $20 \mathrm{~min}$ using Opal antigen retrieval buffer at $\mathrm{pH}$ 6.0. All tissue sections were blocked with antibody diluent for $10 \mathrm{~min}$ at $25^{\circ} \mathrm{C}$. The sections were then incubated with pre-diluted anti-lineagespecific markers (CD31, CD45, CD146, D2-40, and Ecadherin) antibodies (Additional file 1: Table S1) for $1 \mathrm{~h}$ at $25^{\circ} \mathrm{C}$ followed by incubation with horseradish peroxidase (HRP)-conjugated secondary antibodies for $10 \mathrm{~min}$ at $25^{\circ} \mathrm{C}$. A $50 \times$-diluted TSA Plus Working Solution was added to slides and incubated for $10 \mathrm{~min}$ at $25^{\circ} \mathrm{C}$. Slides were stripped via microwave, blocked, and then incubated with pre-diluted anti-CD248 or anti-ITGA8 antibody, HRP-conjugated secondary antibodies and TSA Plus Working Solution were used to amplify signals as described above. All primary antibodies were diluted with antibody diluent (Additional file 1: Table S1). Autofluorescence (negative control) slides were also included.

The slides were counterstained with DAPI for $5 \mathrm{~min}$, mounted with Prolong Gold (Thermo Fisher Scientific), and imaged with a TSC SP8 confocal microscope (Leica, Wetzlar, Germany). Images were processed using LAS X software (Leica).

\section{Quantification of CD248-positive and ITGA8-positive fibroblast-like cells in normal human lungs}

In the multiple immunofluorescence for human lungs, we counted 30 lineage-negative cells and calculated the ratio of CD248 $8^{\text {high }}$ ITGA $8^{\text {low }}$ within lineage-negative cells and CD248 ${ }^{\text {low }}$ ITGA $8^{\text {high }}$ fibroblast-like cells within lineage-negative cells in three normal human lungs. In ten IPF samples, we calculated the ratio of CD248positive and ITGA8-positive fibroblast-like cells as described in Additional file 1: Figure S1.

\section{Statistical analysis}

The obtained results are presented as mean values \pm standard deviations of the results obtained in at least three independent experiments. Statistical analyses were performed using an unpaired Student's $t$-test (two-tailed) for comparisons between two groups, and with one-way analysis of variance and Bonferroni correction for comparisons between more than two groups. $P<0.05$ was considered to represent statistical significance.

\section{Results \\ Isolation of immunophenotypically distinct fibroblasts from the mouse lungs by FACS}

Through FACS analysis, using antibodies against six lineage-specific cell surface markers (lin) (Additional file 1: Table S1), we isolated lin ${ }^{\text {neg }}$ cells from the mouse lungs; this cell population comprised a small number of lineagecommitted cells, including vascular endothelial cells, hematopoietic cells, pericytes, smooth muscle cells, epithelial cells, lymphatic endothelial cells, and erythrocytes (Fig. 1a, left and middle panels). Furthermore, cells were distinguished based on the expression levels of PDGFRA, PDGFRA $^{\text {neg }}$, PDGFRA ${ }^{\text {low }}$, and PDGFRA ${ }^{\text {high }}$ cells (Fig. 1a, right panel). The number of CFUs in the lin $^{\text {neg }}$ PDGFRA ${ }^{\text {high }}$ group was considerably higher than that in the other cultured cell types (Fig. 1b).

In addition to PDGFRA, Sca-1 and Thy- 1 are also used as molecular markers for identifying mouse fibroblasts [6-12]. As shown in Fig. 1c, FACS analysis separated fibroblasts into Sca- $1^{\text {high }}$ Thy-1 ${ }^{\text {low }}$ (A-type fibroblasts) and Sca- $1^{\text {high }}$ Thy- $1^{\text {high }}$ (B-type fibroblasts) from lin${ }^{\text {neg }}$ PDGFRA ${ }^{\text {high }}$ cells. We additionally identified another fibroblast subpopulation, Sca-1 $1^{\text {low }}$ (C-type fibroblasts) that has not been reported to date.

In vitro characterization of immunophenotypically distinct fibroblasts from the mouse lungs

Staining of the fibroblasts with anti- $\alpha$ SMA antibody after 7 days of culture demonstrated that A- and B-type fibroblasts consisted of spindle fibroblast colonies, whereas C-type fibroblasts consisted of polygonal fibroblast colonies with many smooth muscle fibers (Fig. 2a). Protein quantification using FACS revealed significantly 


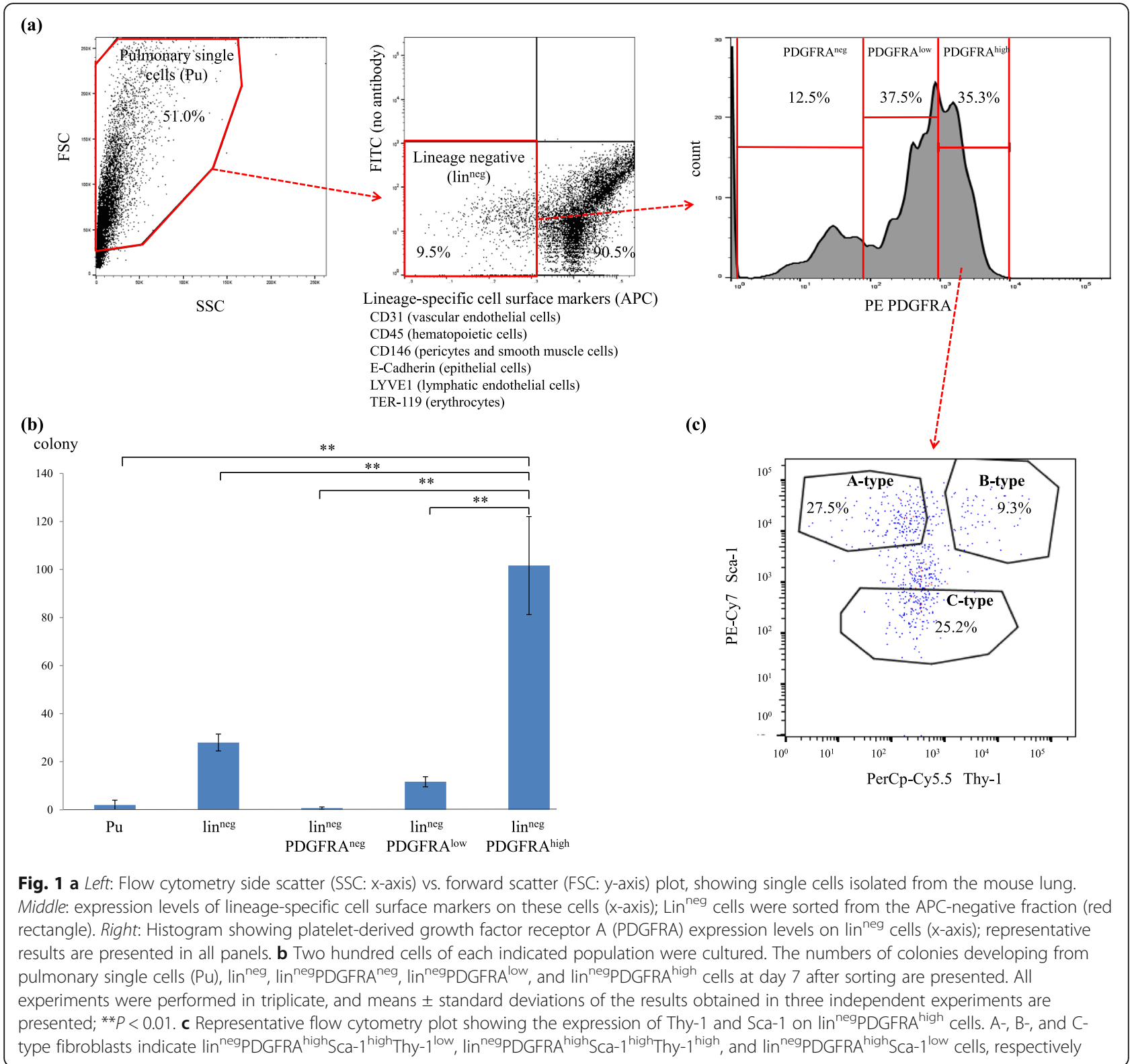

higher expression levels of $\alpha \mathrm{SMA}$ in C-type fibroblasts than in the A- and B-type fibroblasts (Fig. 2b).

Next, we investigated the ability of the isolated fibroblasts to differentiate into osteocytes and adipocytes. Although the cells were cultured in osteogenic differentiation medium, no osteoblast differentiation was observed in any of the cultures, indicating that they were not mesenchymal stem cells (Additional file 1: Figure S2). However, in the adipogenic differentiation medium, some A- and B-type fibroblasts showed lipid droplets and expressed FABP4, which is a specific marker for adipocytes. In contrast, no adipocyte differentiation of C-type fibroblasts was observed (Fig. 2c).
To investigate the proliferative capacity of the different fibroblast subpopulations, we determined the number of fibroblasts after day 1 and day 7 of incubation and calculated the respective proliferation rates. After 7 days in culture, the proliferation rates of A- and B-type fibroblasts were similar and significantly higher than those of C-type fibroblasts (Fig. 2d). In addition, cell cycle analysis using 5-ethynyl-2' -deoxyuridine demonstrated that the rapid cell cycle progression of A- and B-type fibroblasts resulted in their faster proliferation (Additional file 1: Figure S3).

These results indicated that A- and B-type fibroblasts proliferated rapidly, exhibiting partial differentiation into adipocytes, whereas C-type fibroblasts proliferated slowly, 


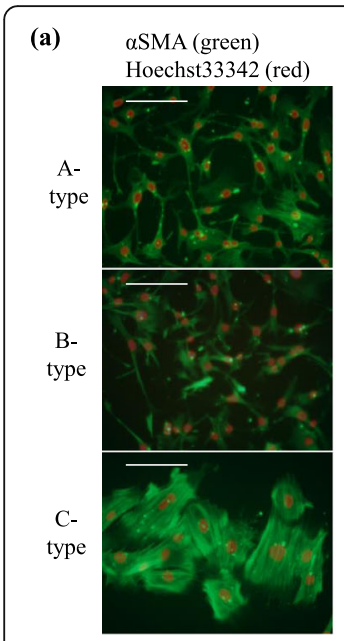

(b)

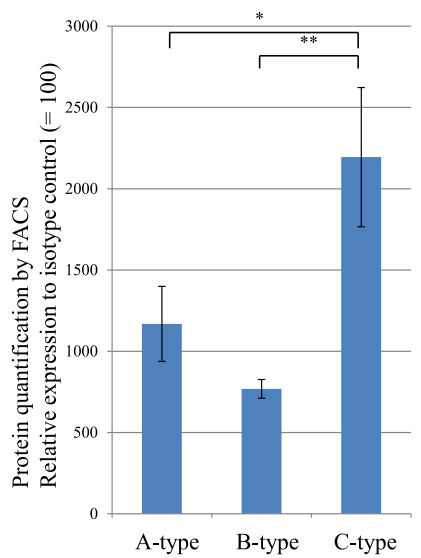

(c)

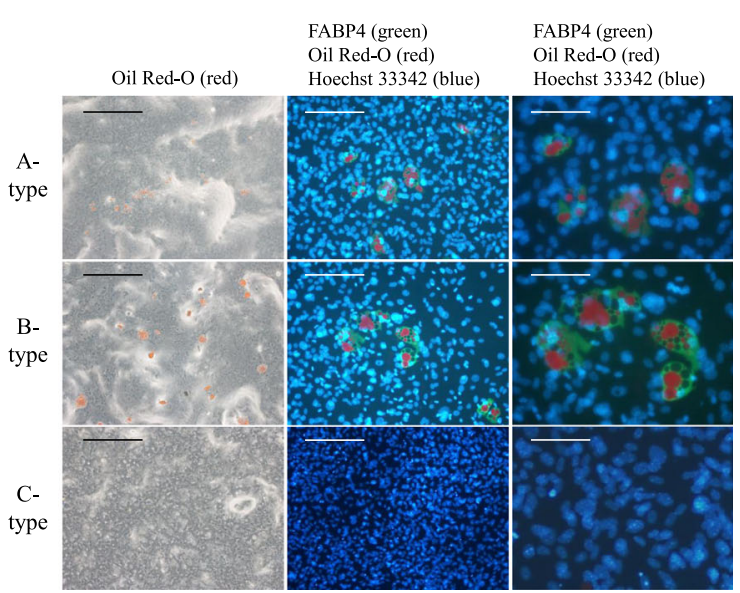

(d)

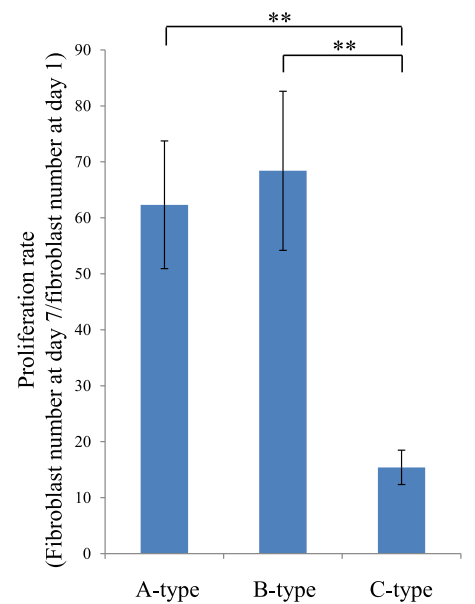

Fig. 2 a Two hundred fibroblasts of the indicated type were cultured for 7 days and stained with Hoechst 33342 (red, nucleus) and anti-aSMA antibody (green); merged images are shown and representative results are presented. Scale bars, $50 \mu \mathrm{m}$. b Protein levels of intracellular aSMA in A-, B-, and C-type fibroblasts cultured for 7 days determined by FACS using FITC-conjugated anti-aSMA antibody, measured relative to the level using FITC-conjugated mouse lgG2a antibody as a control. The experiments were performed in triplicate, and the mean \pm SD of the results obtained in three independent experiments are presented. ${ }^{*} P<0.05$, ${ }^{* *} P<0.01$. c All fibroblast types were cultured until confluence, followed by incubation in the adipogenic differentiation medium for 14 days and stained with Hoechst 33342 (blue, middle and right), anti-fatty acid binding protein 4 (FABP4) antibody (green, middle and right), and Oil Red-O (red, all panels). Merged images are shown (middle and right) and representative results are presented. Scale bars, left, middle $50 \mu \mathrm{m}$; right, $25 \mu \mathrm{m}$. d Proliferation rates of different fibroblast types (fibroblast number at day $7 /$ fibroblast number at day 1). Data represent mean values \pm standard deviations of the results obtained from three independent experiments performed in triplicate; ${ }^{* *} P<0.01$

and exhibited more myofibroblastic differentiation but did not show adipocyte differentiation in vitro.

\section{Gene expression profiling of different fibroblast subtypes from the mouse lungs}

Because the levels of gene expression drastically changed during the culture (Additional file 1: Figure S4), we used mouse lung fibroblasts freshly isolated by FACS to identify any genes specific to each fibroblast subtype. Following amplification of the mRNA of 50,000 cells of each fibroblast subpopulation (A-, B-, and C-type), microarray analysis was performed to compare the gene expression profiles (Additional file 1: Table S2). The gene expression patterns of A- and B-type fibroblasts were similar (Fig. 3a), corresponding to the lack of any significant in vitro biological differences (Fig. 2). Therefore, we did not need to further discriminate between A- and B-type fibroblasts, and they were subsequently classified together into a single fibroblast subtype termed Sca- $1^{\text {high }}$ mouse fibroblasts. Thus, the gene expression profiles of Sca- $1^{\text {high }}$ mouse fibroblasts and Sca- $1^{\text {low }}$ mouse fibroblasts (C-type fibroblasts) were further compared.

According to our identification strategy for Sca- $1^{\text {high }}$ and Sca- $1^{\text {low }}$ mouse fibroblast-specific genes, 23 genes 
(a)

\begin{tabular}{|c|c|c|c|}
\hline & A-type fibroblasts & B-type fibroblasts & C-type fibroblasts \\
\hline Pulmonary single cells (Pu) & 0.81 & 0.81 & 0.81 \\
\hline A-type fibroblasts & & 0.97 & 0.93 \\
\hline B-type fibroblasts & & & 0.93 \\
\hline
\end{tabular}

(c)

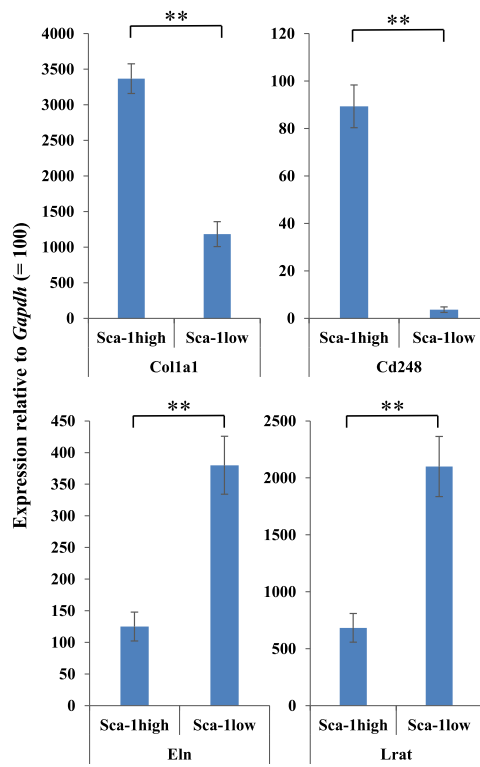

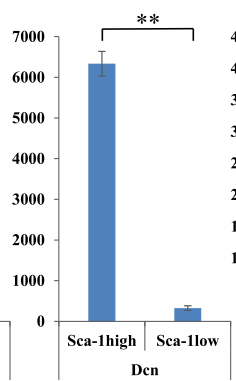

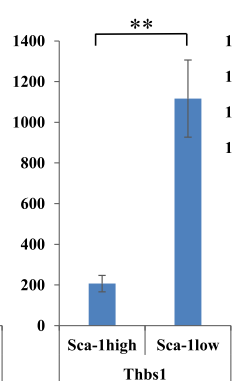

(b)

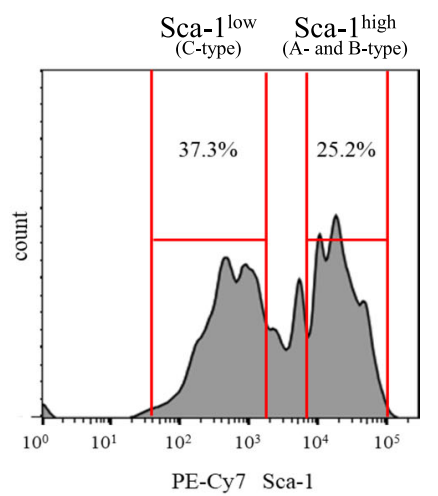

(d)

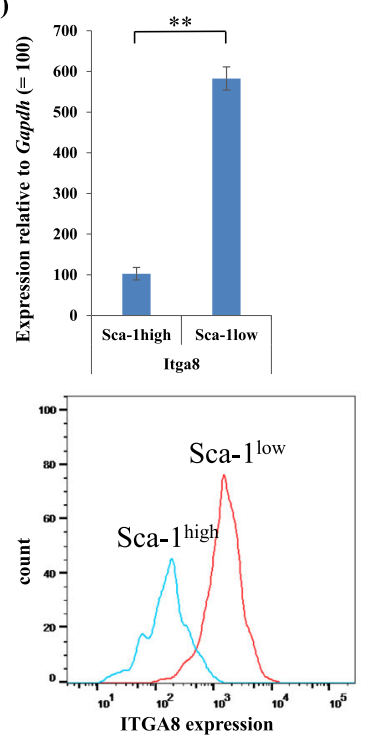

Npnt

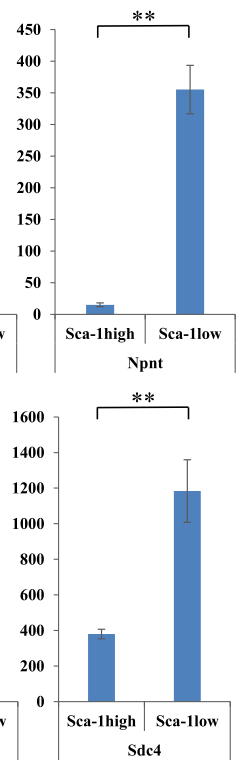

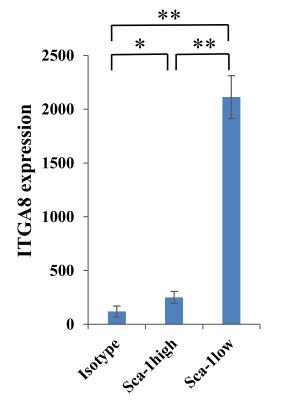

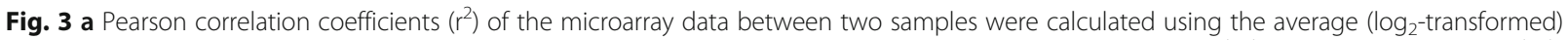
gene expression values. $\mathbf{b}$ Representative flow cytometry plot showing the expression of Sca-1 on lin ${ }^{\text {neg PDGFRA }}{ }^{\text {high }}$ cells (see Fig. 1a). Sca-1 high fibroblasts and Sca-1 ${ }^{\text {low }}$ fibroblasts are indicated. Quantitative PCR for (c) collagen 1a1 (Col1a1), Cd248, decorin (Dcn), nephronectin (Npnt), elastin (EIn), lecithin-retinol acyltransferase (Lrat), thrombospondin (Thbs 1), and syndecan 4 (Sdc4) were performed using prepared cDNA samples of the freshly isolated Sca-1 ${ }^{\text {high }}$ and Sca-1 ${ }^{\text {low }}$ fibroblasts, measured relative to the level of glyceraldehyde-3-phosphate dehydrogenase (Gapdh) for each sample, which was adjusted to 100. Three independent experiments were performed in triplicate. Mean values \pm standard deviations are presented; ${ }^{* *} P<0.01$. d Upper: Quantitative PCR for integrin alpha-8 (Itga8). Lower left: Representative flow cytometry plot showing the

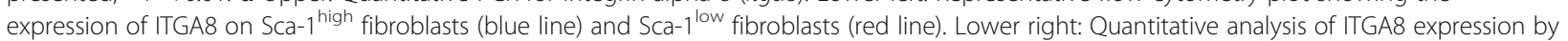
FACS. Isotype indicates flow cytometric analysis using biotin-conjugated goat antibody as a control. Three independent experiments were performed in triplicate. Mean values \pm standard deviations are presented; ${ }^{* *} P<0.01$

were upregulated in Sca- $1^{\text {low }}$ mouse fibroblasts, whereas 36 genes were upregulated in Sca- $1^{\text {high }}$ mouse fibroblasts (Additional file 1: Table S3 and S4). Furthermore, we performed qPCR assay of nine genes that are listed in Additional file 1: Table S3 and S4 to validate the obtained microarray data (Fig. 3c).

\section{ITGA8 is a cell surface marker for Sca- $1^{\text {low }}$ mouse lung fibroblasts}

Because the amount of freshly isolated fibroblasts from the lungs was too small to be used for western blotting, the obtained microarray data were validated by FACS- based protein quantification assay in addition to $\mathrm{qPCR}$ assay.

It was necessary to identify specific cell surface markers of Sca-1 ${ }^{\text {low }}$ mouse fibroblasts. The genes listed in Additional file 1: Table S3 and qPCR results (Fig. 3d) suggested that integrin alpha8 (Itga8) gene was differentially expressed between $\mathrm{Sca}-1^{\text {high }}$ and Sca- ${ }^{\text {low }}$ mouse fibroblasts. Furthermore, FACS-based protein quantification assay confirmed that the expression levels of ITGA8 were significantly higher in Sca- $1^{\text {low }}$ mouse fibroblasts than in Sca- $1^{\text {high }}$ mouse fibroblasts (Fig. 3d). 
Localization of Sca-1 ${ }^{\text {high }}$ and Sca- ${ }^{\text {low }}$ fibroblasts in mouse lungs

To visualize the localization of Sca- $1^{\text {low }}$ fibroblasts and Sca- $1^{\text {high }}$ fibroblasts in mouse lungs, we used antibodies against the lineage-specific cell surface markers (lin), PDGFRA, Sca-1, and ITGA8. Immunofluorescence staining demonstrated that the Sca- $1^{\text {high- }}$ ITGA $8^{\text {low }}$ mouse fibroblasts were localized in the adventitia of pulmonary artery and bronchovascular interstitium, which were the most noticeable collagen fiber (red fiber in EVG stain)-rich connective tissue in mouse lungs (Fig. $4 \mathrm{a}-\mathrm{n}$ ), whereas $\mathrm{Sca}-\mathrm{1}^{\text {low }}$ ITGA $8^{\text {high }}$ mouse fibroblasts were localized in the adventitia of pulmonary vein, which were the most noticeable elastic fiber (black fiber in EVG stain)-rich connective tissue in mouse lungs (Fig. 4). These results indicated that the two immunophenotypically distinct mouse fibroblast subtypes were differently localized in lungs.

As there is no human homolog of mouse Sca-1, it was necessary to identify specific molecular markers of Sca$1^{\text {high }}$ mouse fibroblasts. The genes listed in Additional file 1: Table S4 suggested that Cd248 may be differentially expressed between $\mathrm{Sca}-1^{\text {high }}$ and Sca- $1^{\text {low }}$ mouse fibroblasts. The qPCR assay confirmed that the expression levels of CD248 were much higher in Sca- $1^{\text {high }}$ mouse fibroblasts than in Sca- $1^{\text {low }}$ mouse fibroblasts (Fig. 3c). However, in the present study, we were unable to obtain high-quality results for FACS and immunofluorescence analysis of the mouse lungs using the commercial antibodies against mouse CD248.

The characteristics of the immunophenotypically distinct fibroblast subtypes of mouse lungs are summarized in Table 1.

\section{Localization of different immunophenotypical fibroblast- like cells in normal human lungs}

To reveal the localization of distinct fibroblast subtypes in the normal human lungs, we performed conventional IHC analysis using anti-CD248 antibody or anti-ITGA8 antibody. Further, we conducted multiplex immunofluorescence $\left(\mathrm{Opal}{ }^{\circ}\right)$ using antibodies against lineage-specific markers (CD31 for endothelial cells, CD45 for hematopoietic cells, CD146 for pericytes and smooth muscle cells, D2-40 for lymphatic endothelial cells, and E-cadherin for epithelial cells) in addition to anti-CD248 and anti-ITGA8 antibodies in order to detect lineagespecific markers-negative cells (mostly fibroblasts). As expected, two immunophenotypically different fibroblastlike cells-lineage-specific marker-negative/CD248-high/ ITGA8-low (CD248 ${ }^{\text {high }}$ ITGA $\left.8^{\text {low }}\right)$ fibroblast-like cells and lineage-specific marker-negative/CD248-low/ ITGA8-high $\left(\mathrm{CD} 248^{\text {low }}\right.$ ITGA $\left.8^{\text {high }}\right)$ fibroblast-like cells-were shown to be major subtypes in normal human lungs (Fig. 5a-l, Fig. $6 a-j$, Fig. 7a-h).
The multiplex immunofluorescence followed by the quantification of the number of two subtypes demonstrated that $\mathrm{CD} 248^{\text {high }}$ ITGA $8^{\text {low }}$ human fibroblast-like cells were predominantly distributed in the adventitia of the pulmonary artery (Fig. 8a and Additional file 1: Figure S5), interlobular septum (Fig. 8b), and visceral pleura (Fig. 8c and Additional file 1: Figure S6), which are collagen fiber (red fibers in EVG stain)-rich connective tissue (Fig. 5a-l). By contrast, CD248 ${ }^{\text {low }}$ ITGA $8^{\text {high }}$ human fibroblast-like cells were localized in the adventitia of the pulmonary vein (Fig. $6 \mathrm{k}-\mathrm{o}$ and Fig. 8d) and in the alveolar septum (Fig. $6 \mathrm{k}-\mathrm{o}$ and Fig. 8e), which are elastic fiber (black fibers in EVG stain)-rich connective tissues (Fig. 6a-j).

The distribution of fibroblast-like cell subtypes in the airway wall varied among the different subtypes. CD248 ${ }^{\text {low }}$ ITGA $8^{\text {high }}$ human fibroblast-like cells were the major subtype identified in the bronchiole wall, which are elastic fiber-rich connective tissues (Fig. 7a-d and Fig. 8f). By contrast, CD248 $8^{\text {high }}$ ITGA $8{ }^{\text {low }}$ human fibroblast-like cells were the major subtype identified in the bronchial wall, which are collagen fiber-rich connective tissue (Fig. $7 \mathrm{e}-\mathrm{h}$ and Fig. 8g).

\section{Localization of CD248 ${ }^{\text {high }}$ ITGA $8^{\text {low }}$ fibroblast-like cells and CD248 ${ }^{\text {low }}$ ITGA $8^{\text {high }}$ fibroblast-like cells in other major} human organs

In other major human organs, we immunohistochemically examined the expression of CD248 and ITGA8 in fibroblast-like cells (Additional file 1: Figure S7). In the human dermis, which contains abundant collagen and elastic fibers, conventional IHC demonstrated that dermal fibroblast-like cells expressed CD248 but not ITGA8. Only CD248 $8^{\text {high }}$ fibroblast-like cells were found in intestine and heart like dermis, whereas neither CD248 $8^{\text {high }}$ nor ITGA $8^{\text {high }}$ fibroblast-like cells were found in kidney or liver. During our examination, we did not find CD248 ${ }^{\text {low }}$ ITGA $8^{\text {high }}$ human fibroblast-like cells in other major organs. Thus, the lung is the only organ where CD248 ${ }^{\text {high }}$ ITGA $8^{\text {low }}$ and CD248 ${ }^{\text {low }}$ ITGA $8^{\text {high }}$ human fibroblast-like cells coexisted and were differently localized.

\section{Localization of CD248 ${ }^{\text {high }}$ ITGA $8^{\text {low }}$ fibroblast-like cells and CD248 ${ }^{\text {low }}$ ITGA ${ }^{\text {high }}$ fibroblast-like cells in IPF lungs}

We examined the expression of CD248 and ITGA8 on fibroblast-like cells in IPF lungs by conventional IHC. Figure 9a-d shows a lung lobule in which fibrosis was predominant in the subpleural and paraseptal region, with relatively less fibrosis inside the lobule. Many collagen fibers and CD248 ${ }^{\text {high }}$ ITGA $8^{\text {low }}$ human fibroblast-like cells were found in the same fibrotic regions with a few CD248 ${ }^{\text {low }}$ ITGA $8{ }^{\text {high }}$ human fibroblast-like cells detected (Fig. 9a-d), and the expression levels of CD248 in the 


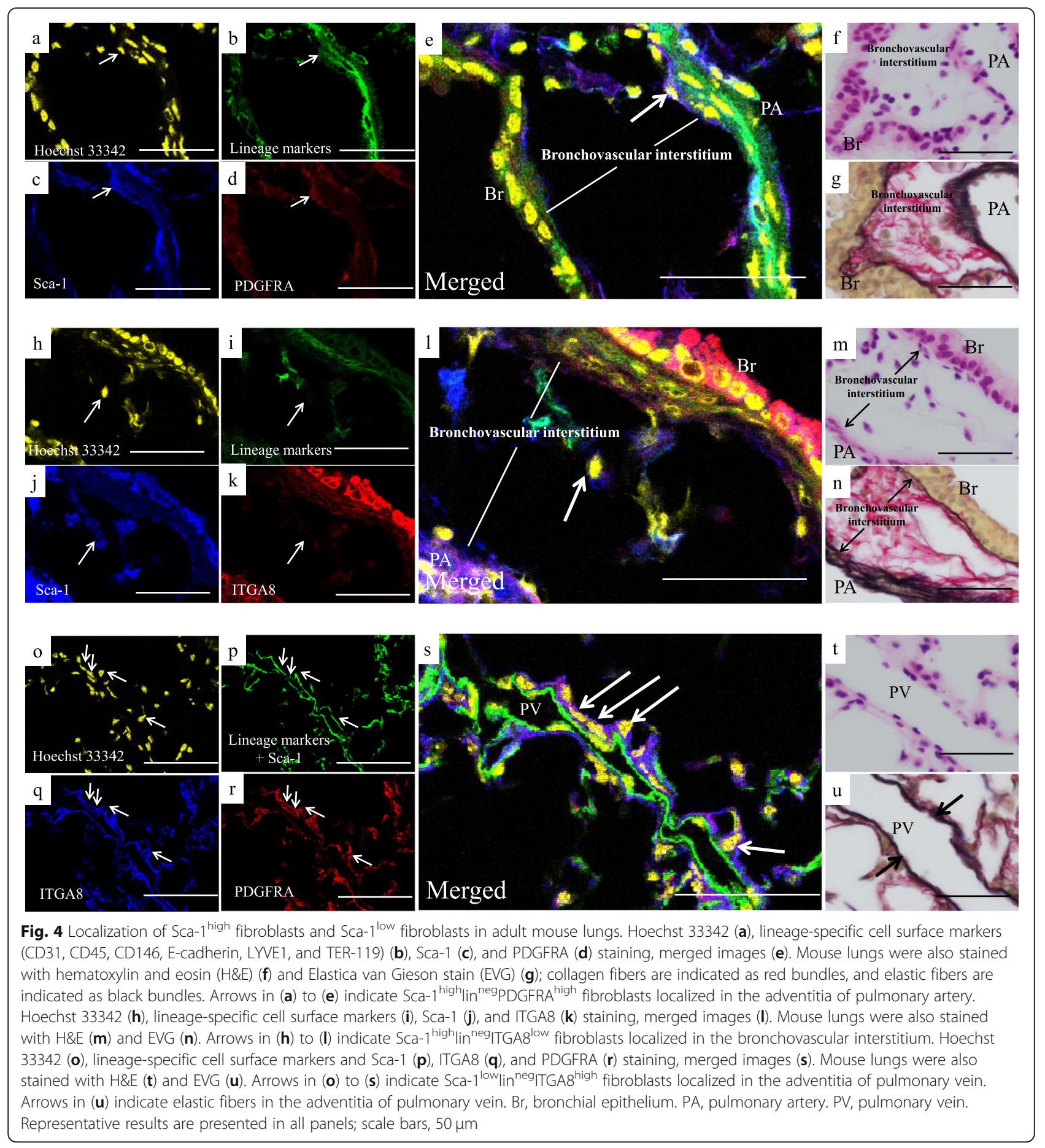

IPF lungs were significantly increased compared with those in the normal lungs (Additional file 1: Figure S8). In the fibrotic regions of all cases, CD248 $8^{\text {high }}$ ITGA $8^{\text {low }}$ human fibroblast-like cells were also localized in the collagen fiber-rich connective tissue (Fig. 9a-l and o), whereas CD248 ${ }^{\text {low }}$ ITGA ${ }^{\text {high }}$ human fibroblast-like cells were localized in the elastic fiber-rich fibrotic connective tissue (Fig. 9e-l and p). CD248 $8^{\text {high }}$ ITGA $8^{\text {low }}$ human fibroblast-like cells were found in the collagen fiber-rich connective tissue of fibroblastic foci, a hallmark of IPF (Fig. 9m-p and q).

\section{Discussion}

The cell surface marker Sca-1, which has been used to identify immunophenotypically distinct mouse lung fibroblasts, is expressed in stem/progenitor cells of 
Table 1 Characteristics of immunophenotypically different fibroblast subtypes in adult mouse lungs

\begin{tabular}{|c|c|c|c|c|c|c|c|c|}
\hline $\begin{array}{l}\text { Type of } \\
\text { fibroblast }\end{array}$ & $\begin{array}{l}\text { Culture cell } \\
\text { morphology }\end{array}$ & Proliferation & $\begin{array}{l}\text { Adipocyte } \\
\text { differentiation }\end{array}$ & $\begin{array}{l}\text { Cd248 } \\
\text { expression }\end{array}$ & $\begin{array}{l}\text { ITGA8 } \\
\text { expression }\end{array}$ & $\begin{array}{l}\text { Col1a1 } \\
\text { expression }\end{array}$ & $\begin{array}{l}\text { Eln } \\
\text { expression }\end{array}$ & Localization in mouse lung \\
\hline Sca-1 $1^{\text {high }}$ & Spindle & Rapid & + & High & Low & High & Low & Collagen fiber-rich connective tissue \\
\hline Sca-1 $1^{\text {low }}$ & Flat & Slow & - & Low & High & Low & High & Elastic fiber-rich connective tissue \\
\hline
\end{tabular}

+: Recognized, -: Not-recognized

various mouse tissues, such as skeletal system, mammary glands, prostate, dermis, skeletal muscle, heart, and liver, in addition to fibroblasts [13]. Sca- $1^{\text {high }}$ and Sca- $1^{\text {low }}$ fibroblast subtypes were found in skin, bone marrow, and thymus [14], but the molecular mechanism of different Sca-1 expression levels between Sca$1^{\text {high }}$ and $\mathrm{Sca}-1^{\text {low }}$ fibroblast subtypes and the biological function of Sca-1 on fibroblasts has not been elucidated.

However, by using multiple antibodies, including antiSca-1 antibody, we identified two distinct mouse lung fibroblast subtypes, including a newly identified subtype $\left(\mathrm{Sca}-1^{\text {low}}\right)$, which differed from the other subtype (Sca- $\left.1^{\text {high }}\right)$ in terms of the in vitro characteristics such as the cultured cell morphology (Fig. 2a), proliferation (Fig. 2b), differentiation (Fig. 2c), and gene expression profiles (Fig. 3). Interestingly, we revealed that the $\mathrm{Sca}-1^{\text {high }}$ mouse fibroblasts and their corresponding CD248 ${ }^{\text {high }}$ ITGA $8^{\text {low }}$ human fibroblast-like cells were localized in the collagen fiber-rich connective tissue, whereas Sca- $1^{\text {low }}$ mouse fibroblasts and their corresponding CD248 ${ }^{\text {low }}$ ITGA $8{ }^{\text {high }}$ human fibroblast- like cells were localized in the elastic fiber-rich connective tissue in normal mouse/human lungs (Fig. 4-8). These IHC results were consistent with the GPCR results of the expression levels of Col1a1 and Eln in Sca- $1^{\text {high }}$ and Sca$1^{\text {low }}$ mouse fibroblasts (Fig. 3c).

The expression of CD248 and Sca-1 was negatively regulated, and the expression of ITGA 8 was positively regulated by transforming growth factor (TGF)- $\beta$, which plays a critical role in the progression of fibrosis of IPF [15-18], suggesting that expression of CD248 and ITGA8 may be potentially changed in the pro-fibrotic state. However, like normal human lungs, the CD248 ${ }^{\text {high }}$ ITGA $8^{\text {low }}$ human fibroblast-like cells were localized in collagen fiberrich connective tissue, and CD248 ${ }^{\text {low }}$ ITGA $8^{\text {high }}$ human fibroblast-like cells were localized in elastic fiber-rich connective tissue (Fig. 9), demonstrating that this classification system of human lung fibroblasts could be used even in IPF lungs.

CD248 is a receptor for type I collagen, which consists of collagen fibers in the connective tissue [19-22]. Therefore,

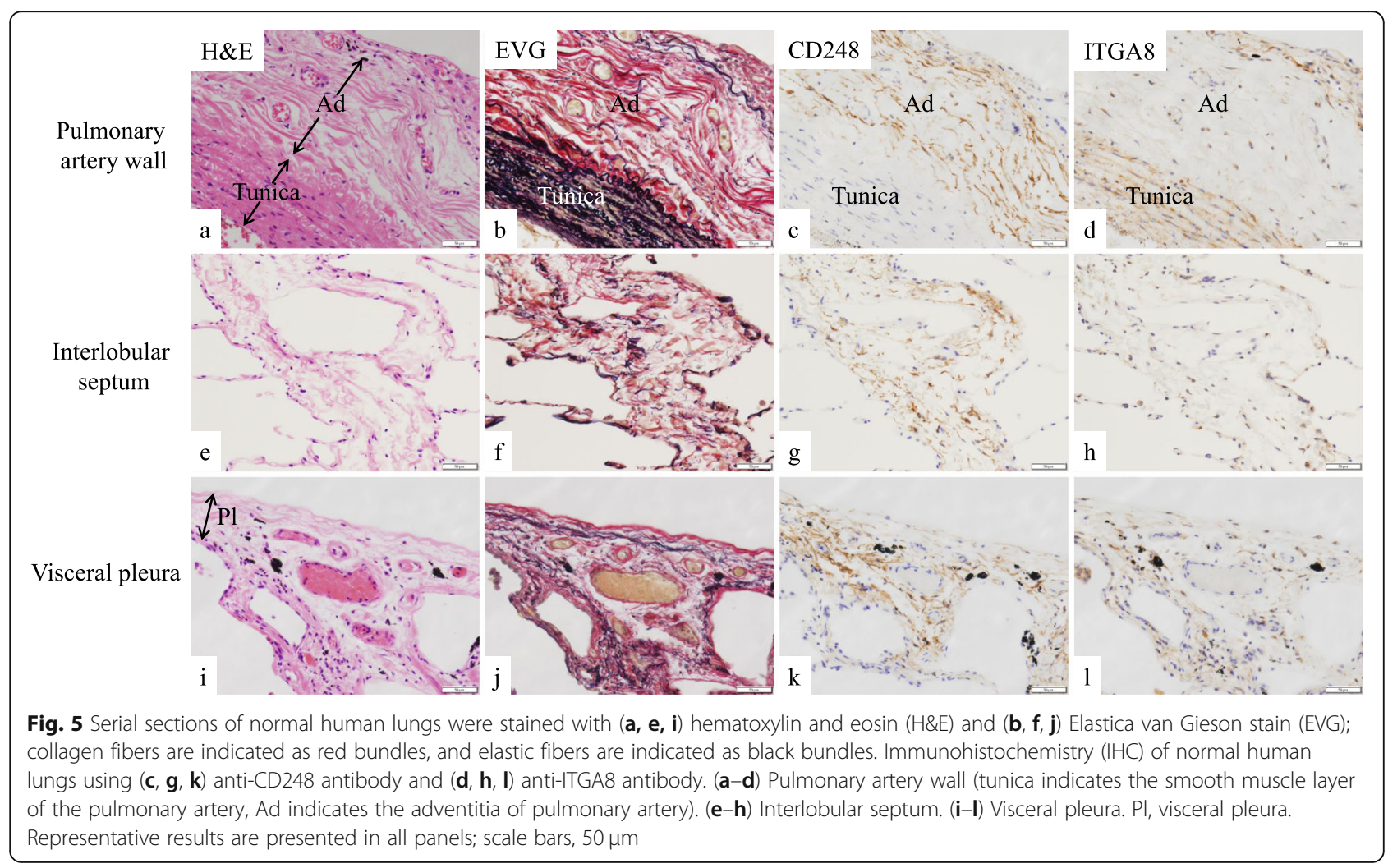



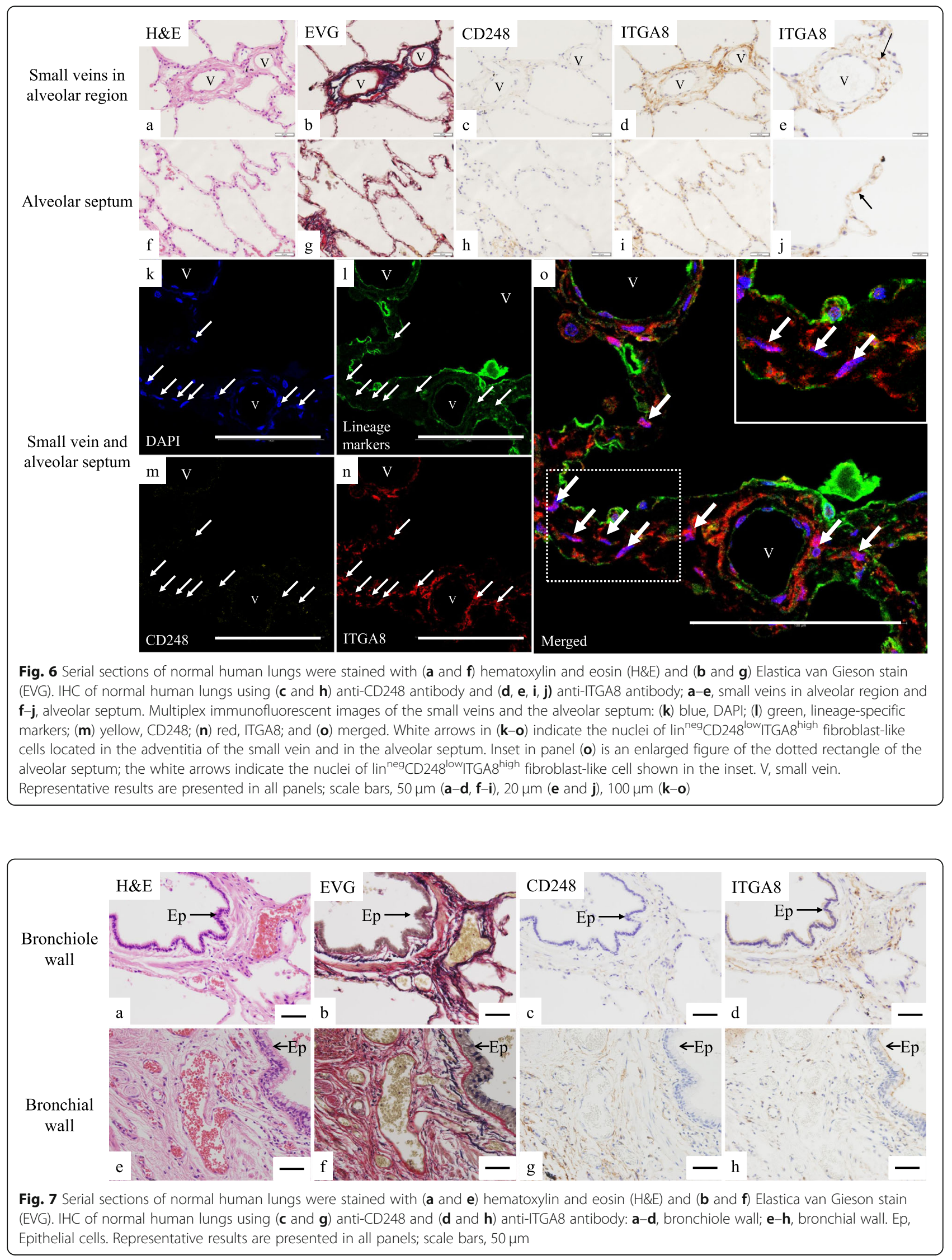

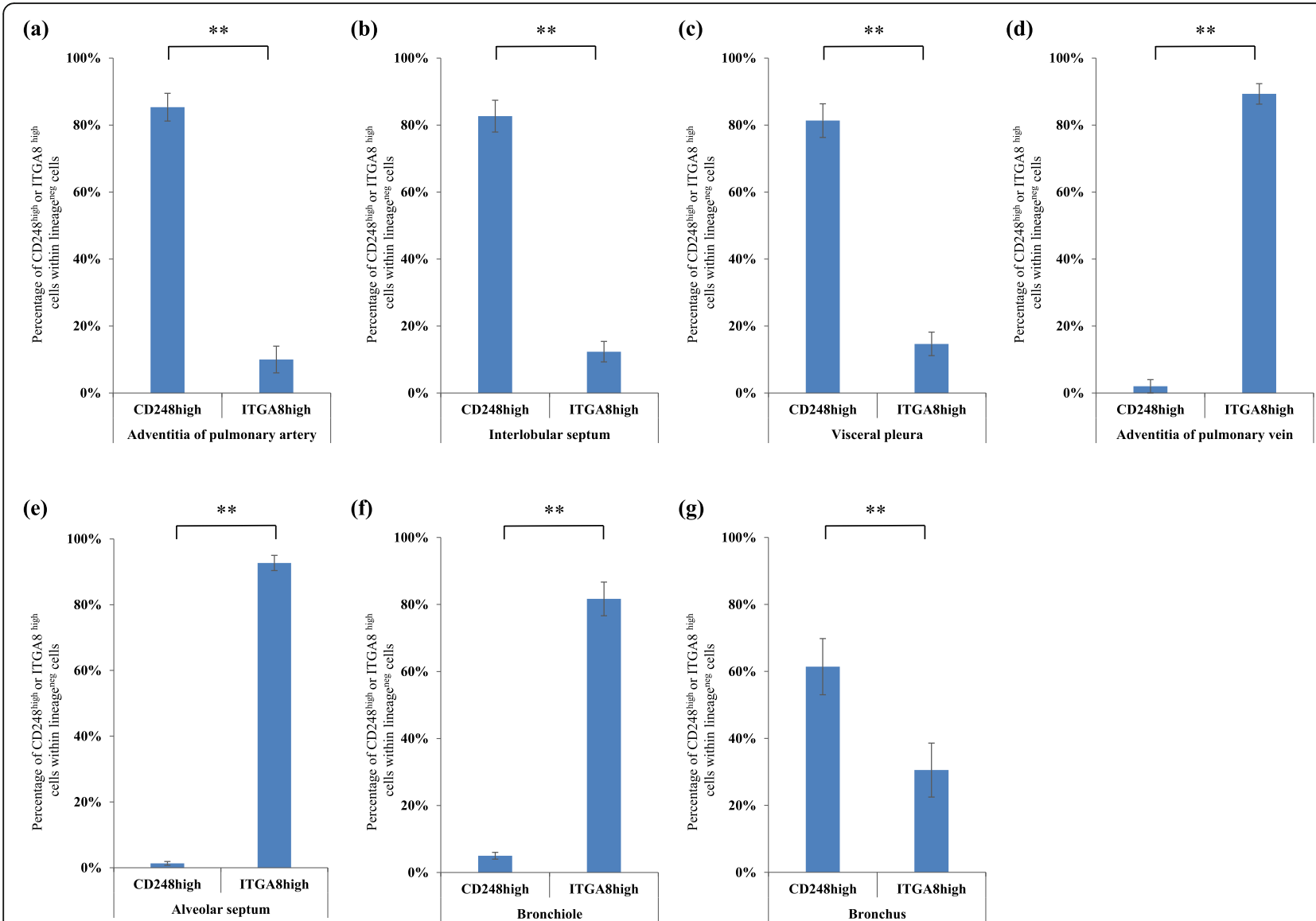

Fig. 8 Quantification of CD248 ${ }^{\text {high }} \mid T G A 8^{\text {low }}$ fibroblast-like cells and CD248 ${ }^{\text {low }} \mid T G A 8^{\text {high }}$ fibroblast-like cells in the seven regions of normal human lungs $(n=4)$ in the multiplex immunofluorescence staining. The ratio of CD248 ${ }^{\text {high }}$ ITGA $8^{\text {low }}$ fibroblast-like cells within lineage-specific markersnegative cells (30 cells) and CD248 ${ }^{\text {low }}$ ITGA $8^{\text {high }}$ fibroblast-like cells within lineage- specific markers-negative cells (30 cells) were calculated. (a) Adventitia of pulmonary artery, (b) Interlobular septum, (c) Visceral pleura, (d) Adventitia of pulmonary vein, (e) Alveolar septum, (f) Bronchiole wall, (g) Bronchial wall. CD248high and ITGA8high $(\mathbf{a}-\mathbf{g})$ indicate CD248 $8^{\text {high } I T G A 8^{\text {low }}}$ fibroblast-like cells and CD248 ${ }^{\text {low }}$ ITGA8 ${ }^{\text {high }}$ fibroblast-like cells, respectively. All experiments were performed in triplicate, and means \pm standard deviations of the results obtained in three independent experiments are presented; ${ }^{* *} P<0.01$

it seems reasonable that $\mathrm{CD} 248^{\text {high }}$ ITGA $8^{\text {low }}$ fibroblast-like cells were always localized in the collagen fiber-rich connective tissues (Figs. 5, 7, 8, and 9). Bartis et al. [23] reported that $\mathrm{CD} 248$ was expressed in the fibroblast-like cells in the fibrotic region of IPF lungs like our results and that the expression levels of CD248 were positively correlated with IPF severity. As shown in the previous study [23], severe IPF lung samples were obtained from lung transplant patients with severe stage IPF. However, we obtained lung samples by VATS, which is generally conducted in mild to moderate stage IPF patients but not in severe stage IPF patients (Additional file 1: Table S6). Therefore, we could not investigate the correlation between severity of IPF and the expression of CD248 and ITGA8 in this study.

CD248 was expressed in the fibroblastic foci (Fig. 9), which histologically characterize IPF and are located in the interface between the fibrotic and the normal parenchyma of the pulmonary lobule [24]. The amount of fibroblastic foci is a significant prognostic factor of IPF [25], and fibroblastic foci itself may be a potential therapeutic target of IPF. Because CD248 ${ }^{\text {high }}$ ITGA $8^{\text {low }}$ human fibroblast-like cells may play an important role in the formation of fibroblastic foci as well as fibrosis in the perilobular (subpleural and/or paraseptal) region (Fig. 9a-d), controlling those fibroblasts may lead to the suppression of fibrosis of IPF. Bartis et al. and Benedetto et al. demonstrated that the reduction of CD248 expression on the fibroblast cell line via siRNA resulted in the reduction of in vitro cell proliferation $[23,26]$, suggesting that $C D 248^{\text {high- }}$ ITGA $8^{\text {low }}$ human fibroblast-like cells are possible candidates as therapeutic targets for IPF lungs. As an anti-fibrotic therapy, CD248 blocking peptide as well as siRNA may be effective tools to suppress the 


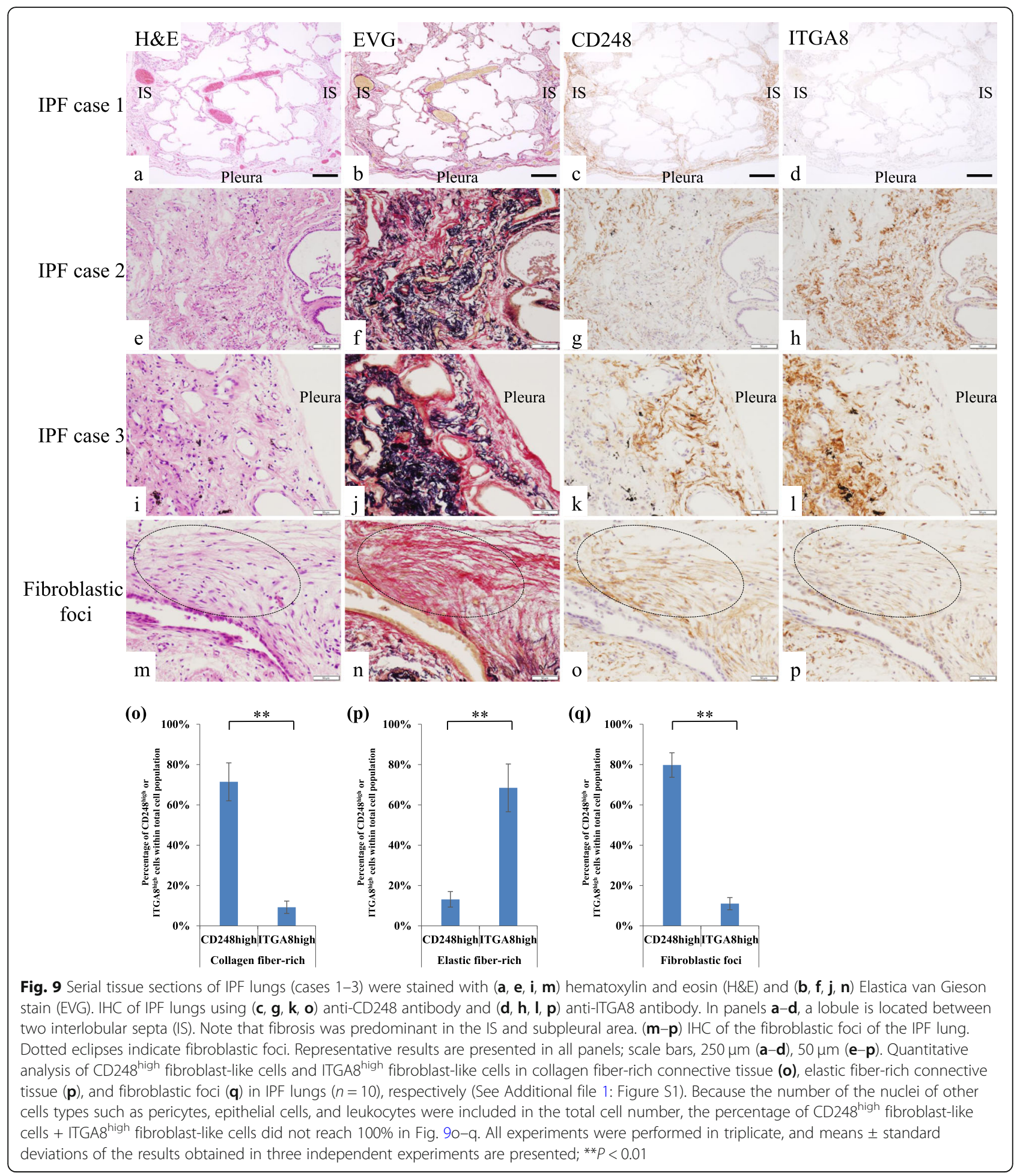

function or expression of CD248 on CD248 ${ }^{\text {high }}$ ITGA $8^{\text {low }}$ human fibroblast-like cells without affecting CD248 ${ }^{\text {low }}$ ITGA $8^{\text {high }}$ human fibroblast-like cells.

ITGA8 was expressed in fibroblast-like cells of the alveolar region of normal human lungs, consistent with previous reports $[27,28]$. Itga ${ }^{-/-}$mice have been reported to show pronounced aberrations in development of the normal lung structure, as evidenced by the presence of wavy and short elastic fibers [29]. In addition, Hung et al. recently demonstrated that fibrotic stimuli by administration of bleomycin induced lung fibrosis in mice in which Itga8 was genetically deleted on platelet-derived growth factor beta-positive 
stromal cells as well as in the control mice, suggesting that ITGA8 was not involved in the collagen production of the mouse lung fibrosis model [30]. These results seem to be consistent with the results that Sca- $1^{\text {low }}$ mouse fibroblasts and their corresponding CD248 $8^{\text {low }}$ ITGA $8^{\text {high }}$ human fibroblast-like cells were localized in the elastic fiber-rich connective tissue but not in collagen fiber-rich connective tissue in normal and IPF lungs (Figs. 6, 7, 8, and 9).

In this study, it was revealed that the distribution of two human lung fibroblasts subtypes was consistent with that of collagen and elastic fibers. Further functional evidence is needed to demonstrate that two fibroblast subsets play an important role in the extracellular matrix deposition and remodeling in fibrotic lungs.

\section{Conclusions}

We identified CD248 and ITGA8 as cell surface markers for human lung fibroblast subtypes. Given their localization, two major subtypes, CD $248^{\text {high }}$ ITGA $8^{\text {low }}$ human fibroblast-like cells and CD248 $8^{\text {low }}$ ITGA $8^{\text {high }}$ human fibroblast-like cells, appear to be associated with collagen fibers and elastic fibers, respectively. This classification system of human lung fibroblasts may be used to conduct further detailed investigations of the functions of different fibroblasts, which will help to gain new insights into lung development and the pathological processes underlying IPF and other fibrotic lung diseases such as pleuroparenchymal fibroelastosis, non-specific interstitial pneumonia, and organizing pneumonia.

\section{Supplementary information}

Supplementary information accompanies this paper at https://doi.org/10. 1186/s12890-020-1054-9.

Additional file 1 Figure S1. Quantification of CD248-positive fibroblastlike cells and ITGA8-positive fibroblast-like cells in collagen fiber-rich connective tissue and elastic fiber-rich connective tissue in IPF lungs. Figure S2. Osteoblast differentiation in mouse fibroblast subtypes. Figure S3. Cell cycle of mouse fibroblast subtypes were analyzed using 5ethynyl-2'-deoxyuridine (EdU). Figure S4. Expression levels of Sca-1 and Itgas during mouse fibroblast culture. Figure S5. Multiple immunofluorescence (IF) images of pulmonary artery wall (media and adventitia) of normal human lung. Figure S6. Multiple IF images of visceral pleura of normal human lung. Figure S7. Localization of CD248 $8^{\text {high }}$ ITGA $88^{\text {low }}$ fibroblast-like cells and CD248 ${ }^{\text {low }}$ ITGA8 $8^{\text {high }}$ fibroblast-like cells in other major human organs. Figure S8. Graphical description of the digital image analysis using the Color Deconvolution ImageJ plugin. Table S1. Details of the antibodies used in this study. Table S2. Microarray analysis results of pulmonary single cells and three immunophenotypically distinct mouse fibroblast types. Table S3. Specific markers associated with Sca-1 ${ }^{\text {low }}$ mouse fibroblast (C-type fibroblast)-specific genes. Table S4. Specific markers associated with Sca- $1^{\text {high }}$ mouse fibroblast (A- and Btype fibroblast)-specific genes. Table S5. Primers used for quantitative PCR used in this study. Table S6. The demographic and clinical data of 10 patients with histologically confirmed IPF.

\section{Abbreviations}

CFU: Colony-forming unit; Col1a1: Collagen 1a1; Den: Decorin; Eln: Elastin; EVG: Elastica van Gieson; FABP4: Fatty acid binding protein 4;

FACS: Fluorescence-activated cell sorting; H\&E: Hematoxylin and eosin;
IPF: Idiopathic pulmonary fibrosis; ITGA8: Integrin alpha-8; lin: Lineage-specific markers; Lrat: Lecithin-retinol acyltransferase; Nont: Nephronectin; PDGFRA: Platelet-derived growth factor receptor type-A; Sdc4: Syndecan 4; Thbs 1: Thrombospondin

\section{Acknowledgements}

The authors thank Mr. Shibata, Mr. Kaneta, Ms. Suzuki, Ms. Kawashima, and Ms. Muranaka for their excellent technical assistance.

\section{Authors' contributions}

Concept and design: SM, TA, YN, TI; data analysis: YA, TF, NE, SM; patient recruitment: YN, NI, KF; FACS and cell culture: KF, SM; IHC and immunofluorescence: SM, IK, HK; preparation of manuscript and figures: SM, YE, TS, TI. All authors have read and approved the manuscript.

\section{Funding}

This work was supported by a Grant-in-Aid for Scientific Research (C) from the Japan Society for the Promotion of Science [grant number 16 K08736]. The funder gave economical support to the study, but was not involved in the design of the study and collection, analysis, interpretation of data or in writing the manuscript.

\section{Availability of data and materials}

All relevant data and materials are published in the manuscript and supplementary materials.

\section{Ethics approval and consent to participate}

All procedures in this study were performed in accordance with approval from the local research ethics committees at the Hamamatsu University School of Medicine. This study was approved by the Animal Care and Use Committee of Hamamatsu University School of Medicine (approval number: 2015008). All animal experiments and procedures complied with ARRIVE guidelines, and were carried out in accordance with the National Institutes of Health Guide for the Care and Use of Laboratory Animals. With respect to the use and collection of human tissue samples, all patients included in this study gave a written informed consent for the use of their tissue. This study was approved by the Institutional Review Board of Hamamatsu University School of Medicine (approval number: 15-197).

\section{Consent for publication}

Not applicable.

\section{Competing interests}

The authors declare that they have no competing interests related to this publication.

\section{Author details}

${ }^{1}$ Department of Regenerative and Infectious Pathology, Hamamatsu University School of Medicine, 1-20-1 Handayama, Higashi-ku, Hamamatsu City, Shizuoka 431-3192, Japan. ${ }^{2}$ Second Division, Department of Internal Medicine, Hamamatsu University School of Medicine, 1-20-1 Handayama, Higashi-ku, Hamamatsu City, Shizuoka 431-3192, Japan. ${ }^{3}$ Division of Respiratory Medicine, Shizuoka General Hospital, 4-27-1 Kita Ando Aoi-ku, Shizuoka City, Shizuoka 420-8527, Japan. ${ }^{4}$ Department of Clinical Pharmacology and Therapeutics, Hamamatsu University School of Medicine, 1-20-1 Handayama, Higashi-ku, Hamamatsu City, Shizuoka 431-3192, Japan. ${ }^{5}$ First Department of Surgery, Hamamatsu University School of Medicine, 1-20-1 Handayama, Higashi-ku, Hamamatsu City, Shizuoka 431-3192, Japan.

Received: 3 May 2019 Accepted: 13 January 2020

Published online: 21 January 2020

\section{References}

1. Phan SH. Biology of fibroblasts and myofibroblasts. Proc Am Thorac Soc. 2008:5:334-7.

2. Driskell RR, Lichtenberger BM, Hoste E, Kretzschmar K, Simons BD, Charalambous M, Ferron SR, Herault Y, Pavlovic G, Ferguson-Smith AC, Watt FM. Distinct fibroblast lineages determine dermal architecture in skin development and repair. Nature. 2013;504:277-81.

3. Öhlund D, Elyada E, Tuveson D. Fibroblast heterogeneity in the cancer wound. J Exp Med. 2014;211:1503-23. 
4. Driskell RR, Watt FM. Understanding fibroblast heterogeneity in the skin. Trends Cell Biol. 2015;25:92-9.

5. Smith ML. Update on pulmonary fibrosis: not all fibrosis is created equally. Arch Pathol Lab Med. 2016;140:221-9.

6. Akamatsu T, Arai Y, Kosugi I, Kawasaki H, Meguro S, Sakao M, Shibata K, Suda T, Chida K, Iwashita T. Direct isolation of myofibroblasts and fibroblasts from bleomycin-injured lungs reveals their functional similarities and differences. Fibrogenesis Tissue Repair. 2013;6:15.

7. Hagood JS, Prabhakaran P, Kumbla P, Salazar L, MacEwen MW, Barker TH, Ortiz LA, Schoeb T, Siegal GP, Alexander CB, et al. Loss of fibroblast Thy-1 expression correlates with lung fibrogenesis. Am J Pathol. 2005;167:365-79.

8. Sanders YY, Kumbla P, Hagood JS. Enhanced myofibroblastic differentiation and survival in Thy-1(-) lung fibroblasts. Am J Respir Cell Mol Biol. 2007;36:226-35.

9. McQualter JL, Brouard N, Williams B, Baird BN, Sims-Lucas S, Yuen K, Nilsson SK, Simmons PJ, Bertoncello I. Endogenous fibroblastic progenitor cells in the adult mouse lung are highly enriched in the sca-1 positive cell fraction. Stem Cells. 2009;27:623-33.

10. Varisco BM, Ambalavanan N, Whitsett JA, Hagood JS. Thy-1 signals through PPARy to promote lipofibroblast differentiation in the developing lung. Am J Respir Cell Mol Biol. 2012;46:765-72.

11. Phipps RP, Penney DP, Keng P, Quill H, Paxhia A, Derdak S, Felch ME. Characterization of two major populations of lung fibroblasts: distinguishing morphology and discordant display of thy 1 and class II MHC. Am J Respir Cell Mol Biol. 1989:1:65-74.

12. Phipps RP, Baecher C, Frelinger JG, Penney DP, Keng P, Brown D. Differential expression of interleukin 1 alpha by Thy-1+ and Thy-1- lung fibroblast subpopulations: enhancement of interleukin 1 alpha production by tumor necrosis factor-alpha. Eur J Immunol. 1990;20:1723-7.

13. Holmes C, Stanford WL. Concise review: stem cell antigen-1: expression, function, and enigma. Stem Cells. 2007;25:1339-47.

14. Patenaude J, Perreault C. Thymic Mesenchymal cells have a distinct Transcriptomic profile. J Immunol. 2016;196:4760-70.

15. Long KK, Montano M, Pavlath GK. Sca-1 is negatively regulated by TGFbeta1 in myogenic cells. FASEB J. 2011;25:1156-65.

16. Suresh Babu S, Valdez Y, Xu A, O'Byrne AM, Calvo F, Lei V, Conway EM TGF $\beta$-mediated suppression of CD248 in non-cancer cells via canonical Smad-dependent signaling pathways is uncoupled in cancer cells. BMC Cancer. 2014;14:113.

17. Bryukhovetskiy I, Shevchenko V. Molecular mechanisms of the effect of TGF$\beta 1$ on U87 human glioblastoma cells. Oncol Lett. 2016;12:1581-90.

18. Fernandez IE, Eickelberg O. The impact of TGF- $\beta$ on lung fibrosis: from targeting to biomarkers. Proc Am Thorac Soc. 2012;9:111-6

19. Tomkowicz B, Rybinski K, Foley B, Ebel W, Kline B, Routhier E, Sass P, Nicolaides NC, Grasso L, Zhou Y. Interaction of endosialin/TEM1 with extracellular matrix proteins mediates cell adhesion and migration. Proc Nat Acad Sci U S A. 2007;104:17965-70.

20. Christian S, Winkler R, Helfrich I, Boos AM, Besemfelder E, Schadendorf D, Augustin HG. Endosialin (Tem1) is a marker of tumor-associated myofibroblasts and tumor vessel-associated mural cells. Am J Pathol. 2008:172:486-94

21. Wienke D, MacFadyen JR, Isacke CM. Identification and characterization of the endocytic transmembrane glycoprotein Endo180 as a novel collagen receptor. Mol Biol Cell. 2003;14:3592-604.

22. MacFadyen JR, Haworth $\mathrm{O}$, Roberston D, Hardie D, Webster MT, Morris HR, Panico M, Sutton-Smith M, Dell A, van der Geer P, et al. Endosialin (TEM1, CD248) is a marker of stromal fibroblasts and is not selectively expressed on tumour endothelium. FEBS Lett. 2005;579:2569-75.

23. Bartis D, Crowley LE, D'Souza VK, Borthwick L, Fisher AJ, Croft AP, Pongrácz JE, Thompson R, Langman G, Buckley CD, Thickett DR. Role of CD248 as a potential severity marker in idiopathic pulmonary fibrosis. BMC Pulm Med. 2016;16:51.

24. Robbie H, Daccord C, Chua F, Devaraj A. Evaluating disease severity in idiopathic pulmonary fibrosis. Eur Respir Rev. 2017;26.

25. Enomoto N, Suda T, Kato M, Kaida Y, Nakamura Y, Imokawa S, Ida M, Chida K. Quantitative analysis of fibroblastic foci in usual interstitial pneumonia. Chest. 2006;130:22-9.

26. Di Benedetto P, Liakouli V, Ruscitti P, Berardicurti O, Carubbi F, Panzera N, Di Bartolomeo S, Guggino G, Ciccia F, Triolo G, et al. Blocking CD248 molecules in perivascular stromal cells of patients with systemic sclerosis strongly inhibits their differentiation toward myofibroblasts and proliferation: a new potential target for antifibrotic therapy. Arthritis Res Ther. 2018;20:223.

27. Levine D, Rockey DC, Milner TA, Breuss JM, Fallon JT, Schnapp LM. Expression of the integrin alpha8beta1 during pulmonary and hepatic fibrosis. Am J Pathol. 2000;156:1927-35.

28. Wagner TE, Frevert CW, Herzog EL, Schnapp LM. Expression of the integrin subunit alpha8 in murine lung development. J Histochem Cytochem. 2003:51:1307-15.

29. Benjamin JT, Gaston DC, Halloran BA, Schnapp LM, Zent R, Prince LS. The role of integrin alphasbeta1 in fetal lung morphogenesis and injury. Dev Biol. 2009;335:407-17.

30. Hung CF, Wilson CL, Chow YH, Schnapp LM. Role of integrin alpha8 in murine model of lung fibrosis. PLoS One. 2018;13:e0197937.

\section{Publisher's Note}

Springer Nature remains neutral with regard to jurisdictional claims in published maps and institutional affiliations.

\section{Ready to submit your research? Choose BMC and benefit from:}

- fast, convenient online submission

- thorough peer review by experienced researchers in your field

- rapid publication on acceptance

- support for research data, including large and complex data types

- gold Open Access which fosters wider collaboration and increased citations

- maximum visibility for your research: over $100 \mathrm{M}$ website views per year

At BMC, research is always in progress.

Learn more biomedcentral.com/submissions 